\title{
PENGARUH MODEL PEMBELAJARAN PAPAN MEMORI TERHADAP KEMAMPUAN MEMAHAMI PEMBACAAN CERPEN PADA SISWA KELAS XI MA NEGERI BANTARKALONG TASIKMALAYA
}

\author{
Ai Siti Nurjamilah \\ aisitinurjamilah@unsil.ac.id \\ Jurusan Pendidikan Bahasa Indonesia \\ FKIP, Universitas Siliwangi Tasikmalaya
}

\begin{abstract}
Abstrak
Penelitian ini dilaksanakan dengan tujuan untuk memperoleh informasi mengenai pengaruh model pembelajaran Papan Memori dalam pembelajaran menyimak pembacaan cerita pendek pada siswa kelas X1 IPS 1 MAN Bantarkalong Tasikmalaya. Dalam penelitian ini digunakan metode eksperimen dengan rancangan kelompok prates dan pascates. Populasinya, semua peserta didik kelas XI MA Negeri 1 Bantarkalong Tasikmalaya jurusan IPA dan IPS. Sampel diambil secara diundi dan terpilih satu jurusan, yakni jurusan IPS; karena jurusan IPS terdapat dua kelas, IPS 1 dan IPS 2, sehingga harus melakukan pengundian dalam menentukan kelas eksperimen dan kelas kontrol. Berdasarkan hasil pengundian, terpilih kelas XI IPS 1 sebagai kelas eksperimen yang pada pembelajarannya menggunakan model pembelajaran Papan Memori dan kelas XI IPS 2 sebagai kelas kontrol dengan model pembelajaran yang biasa digunakan oleh guru setempat. Instrumen yang digunakan adalah prates dan pascates kemampuan analisis cerpen. Penelitian yang telah dilaksanakan menunjukkan bahwa model pembelajaran Papan Memori mampu meningkatkan kemampuan siswa dalam memahami cerita pendek. Hal ini dapat dibuktikan dengan adanya perbandingan nilai yang didapatkan oleh peserta didik pada kelas eksperimen lebih bagus daripada yang diperoleh siswa kelas kontrol dalam kemampuan mengapresiasi cerita pendek. Artinya model pembelajaran Papan Memori merupakan model yang cocok untuk diterapkan atau diaplikasikan dalam pembelajaran kemampuan memahami cerita pendek.
\end{abstract}

Kata kunci: Pembelajaran kooperatif, model papan memori, analisis cerpen.

\begin{abstract}
This study aims to obtain information about the effect of memory board learning models in learning to listen to short story readings in class XI IPS 1 MAN Bantarkalong Tasikmalaya. The method used in this study is an experimental method with pre-test and post-test group design. The population in this study were all students of class XI MA Negeri 1 Bantarkalong Tasikmalaya majoring in Science and Social Sciences. Samples were drawn in draws and one department was chosen, namely the Social Sciences Department. Because there are two classes in the social studies department, IPS 1 and IPS 2, the draw is conducted to determine the experimental class and control class. Based on the draw results, class XI IPS 1 was chosen as the experimental class which in its learning used a memory board learning model and class XI IPS 2 as a control class with a learning model commonly used by local teachers. The instrument in this study is pre-test and posttest analysis skills. Based on the results of the study showed that the memory board learning model is able to improve students' ability to understand short stories. This can be proven by the comparison of the values obtained by students in the experimental class better than those obtained by control class students in the ability to appreciate short stories. This means that the memory board learning model is a suitable model to be applied or applied in the ability to understand short stories.

Keywords: cooperative learning, memory board model, short story analysis.
\end{abstract}

\section{PENDAHULUAN}

Para peminat dan pemerhati sastra seringkali mengeluhkan kondisi pembelajaran kebahasaan dan kesastraan cenderung didominasi oleh pembelajaran kebahasaan. Guru-guru kita pada umumnya lebih berminat dan menguasai bidang kebahasaan daripada bidang kesastraan. Dalam hal ini, penulis membahas pada bidang kesastraan dalam hal menganalisis cerpen. Kenyataan di lapangan, banyak siswa yang belum mampu menganalisis cerpen. Cerpen dianggap sebagai 
sesuatu yang sulit. Anggapan tersebut muncul karena siswa kurang tertarik dalam bidang kesastraan, terutama dalam hal membaca dan menganalisis cerpen. Permasalahan selalu muncul pada setiap kegiatan pembelajaran. Hal tersebut berkaitan dengan beberapa faktor yang dapat mempengaruhi proses dan hasil pembelajaran.

Jamaluddin (2003: 70) mengungkapkan, terdapat delapan faktor yang diidentifikasi sebagai penyebab gagalnya pembelajaran sastra di sekolah-sekolah selama ini.

1.Mitos negatif dalam dunia sastra.

2.Dunia sastra yang selalu terpencil.

3.Teori sastra versus kebebasan kreatif seniman.

4.Kesalahan konsep dalam
pembelajaran sastra. pembelajaran sastra.

$\begin{array}{llr}\begin{array}{l}\text { 5.Dongeng } \\ \text { keterbatasan } \\ \text { pembelajaran. }\end{array} & \text { alokasi } & \begin{array}{r}\text { tentang } \\ \text { waktu }\end{array} \\ & & \end{array}$

6.Pola pembelajaran dan sistem evaluasinya.

7.Minimnya jumlah buku pelajaran.

8.Profesionalitas guru yang dipertanyakan.

Salah satu yang termasuk bidang sastra yang banyak dipelajari di sekolah, yakni mengenai cerpen. Pada kenyataannya masih banyak siswa yang tidak menyukai cerpen dan tidak mampu untuk menganalisisnya. Berdasarkan hal tersebut, penulis merasa tergugah untuk melakukan penelitian mengenai hal itu. Ketidakmampuan siswa dalam memahami cerpen bukan hanya karena semata-mata ia tidak menyukai cerpen tetapi dapat pula disebabkan oleh faktor guru. Guru sering kebingungan dalam memilih metode yang tepat untuk pembelajaran sastra yang menarik bagi para siswanya. Berdasarkan permasalahan tersebut, penulis melaksanakan penelitian mengenai pemahaman pembacaan cerpen dengan cara mengujicobakan salah satu model pembelajaran, yakni model pembelajaran Papan Memori.

Tujuan penulis menggunakan model Papan Memori dalam pembelajaran cerpen, yakni agar siswa mampu mendefinisikan mengenai istilah yang ada dalam unsur intrinsik sebuah cerpen sehingga siswa mampu menganalisis cerpen. Pada aktivitas pembelajaran diperlukan keterlibatan kerja aktif otak sehingga dapat meningkatkan kemampuan kognitif siswa. Permainan yang terkandung di dalamnya, memberi keceriaan pada tugas-tugas belajar. Siswa bisa mengemukakan gagasan yang ada dalam pikirannya dan menjadi kreatif. Hal ini membuat belajar menjadi lebih ceria dan aktif.

Kegiatan pembelajaran bahasa mempunyai peranan yang penting dalam pengembangan intelektual, emosional, dan sosial. Peserta didik diarahkan pada kegiatan yang bertujuan untuk meningkatkan kemampuan ketika berkomunikasi secara baik dan juga benar, baik dalam komunikasi secara lisan ataupun tulis dan meningkatkan apresiasi terhadap hasil karya sastra. Berkaitan dengan ini, guru dapat menekankan perhatian pada 
pengembangan kemampuan

berbahasa peserta didik dengan melakukan bermacam kegiatan serta secara leluasa menentukan bahan ajar yang sesuai dengan keadaan lingkungan sekolah dan kemampuan semua peserta didiknya.

Penggunaan model pembelajaran Papan Memori, peserta didik lebih menyukai serta menggunakan karya sastra untuk menambah wawasan, memperhalus budi pekerti, dan menambah ilmu pengetahuan serta kemampuan berbahasa. Berdasarkan permasalahan yang sudah diuraikan, penulis bermaksud melaksanakan penelitian dengan menggunakan model eksperimen karena bersifat mengujicobakan sebuah model pembelajaran.

\section{KAJIAN TEORI}

Tujuan pembelajaran memahami pembacaan cerpen berdasarkan kurikulum, sebagai berikut.

a. Dapat meningkatkan kemampuan peserta didik dalam mencapai tingkat kualifikasi unggul.

b. Dapat mengaplikasikan kemampuan berbahasa Indonesia yang baik dan benar pada mata pelajaran lainnya.

c. Dapat meningkatkan kemampuan berkomunikasi secara efisien dan efektif, baik secara lisaan maupun tulis.

d. Meningkatkan kompetensi berbahasa Indonesia untuk bekerja.
Uraian tersebut mengisyaratkan bahwa siswa diharapkan mampu memahami isi cerpen yang dibacakan dan menemukan nilai yang terkandung di dalamnya. Harapan lebih jauh, siswa dapat meningkat ilmu pengetahuannya, halus budi pekertinya, dan dapat mengaplikasikannya dalam kehidupan. Selain itu, siswa dapat mengomunikasikan hal baik yang terdapat dalam isi cerpen dengan menggunakan bahasa Indonesia yang baik dan benar sehingga akhirnya jelaslah sudah bahwa pembelajaran bahasa Indonesia mengarahkan peserta didik pada kemampuan untuk berkomunikasi secara baik dan benar, karena di zaman global penggunaan bahasa dengan baik dan benar adalah sebuah syarat mutlak pada dunia kerja dalam menghadapi tantangan masa depan.

\section{Hakikat Model Pembelajaran Papan Memori}

Model pembelajaran Papan Memori merupakan model kooperatif karena memusatkan kegiatan pembelajaran pada proses dengan menekankan kerja sama di dalam berkelompok. Menurut Ginnis (2008: 146), "Model Papan Memori adalah model pembelajaran yang menyenangkan karena disajikan dalam bentuk permainan yang cepat dan mudah". Model pembelajaran Papan Memori menggunakan papan tulis sebagai medianya yang dapat membantu siswa dalam memahami dan menganalisis unsur intrinsik 
serta nilai yang terkandung dalam cerpen.

Mengacu pada pengertian
model Papan Memori yang dikemukakan Ginnis di atas, maka penulis mendefinisikan model Papan Memori adalah model pembelajaran yang dilaksanakan dengan menyediakan daftar istilah unsur intrinsik cerpen dan uraian istilah tersebut yang dituliskan di papan tulis. Papan Memori yang dimaksud disini adalah papan tulis. Pembelajaran model ini dilaksanakan dengan bekerja sama, bertukar pikiran. Daftar istilah atau materi tersebut berdasarkan hasil pemikiran para peserta didik yang tentunya atas dasar arahan guru. Setelah peserta didik memahami isi yang tercantum dalam papan tulis, materi yang diuraikan pada papan tulis akan dihapus dan peserta didik diminta untuk mampu menjelaskan kembali apa yang tertera pada papan tulis tadi. Hal tersebut bertujuan dalam peningkatan kemampuan kognitif, apektif dan psikomotorik para peserta didik. Keterampilan dasar yang harus dimiliki oleh siswa seperti berpikir logis, mengomunikasikan ide dan fakta, dan mengontruksi kalimat seharusnya sudah dipelajari oleh siswa. Dengan demikian, peserta didik tidak hanya mampu dalam bidang sastra saja tetapi juga dalam berbahasa karena sikap berbahasa siswa dalam proses menjelaskan kembali materi sebelumnya pun diperhatikan. Penjelasan tersebut senada dengan tujuan utama kegiatan

198 | Jurnal Kredo Vol. 2 No. 2 April 2019 pembelajaran bahasa Indonesia yang terdapat dalam kurikulum yaitu para pembelajar dapat berkomunikasi secara efektif dan efisien yang sesuai aturan yang berlaku, baik secara lisan maupun tulis, peserta didik bisa menikmati serta menggunakan karya sastra sebagai alat untuk menambah pengetahuan, memperhalus budi pekerti, serta meningkatkan kemampuan dalam berbahasa.

Tahapan

pembelajaran kooperatif tipe papan memori menurut Ginnis (2008: 146) sebagai berikut.

1.Tulis satu lusin atau lebih istilah teknis di papan tulis, yang diambil dari topik yang baru selesai atau topik yang sedang direvisi setelah beberapa waktu. Akan tetapi, lebih baik, tulis istilah-istilah tersebut sebelumnya di transparansi OHP.

2.Beri siswa satu menit untuk mengingat daftar.

3.Setelah waktu habis, hapus tulisan, atau putar papannya, atau matikan OHP.

4.Siswa harus menulis sendiri bukan istilah tersebut, tetapi definisinya, dengan mengingat sebanyak yang mereka mampu dalam jarak waktu tertentu.

5. Kembali ke istilah tersebut dan bahas berbagai cara yang digunakan siswa untuk mendefinisikannya.

Berdasarkan tahapan pembelajaran Papan Memori yang dikemukakan Ginnis di atas, maka penulis sedikit memodifikasi tahapan 
pembelajaran papan memori tersebut menjadi sebagai berikut.

1.Siswa bersama kelompoknya mempelajari topik atau istilah yang telah mereka dapatkan berdasarkan hasil undian.

2.Setiap anggota kelompok ikut serta berkontribusi atas usaha-usaha yang dilakukan kelompoknya.

3. Siswa berdiskusi mengenai materi yang harus dipelajarinya.

4.Setiap anggota kelompok merancang yang akan mereka sampaikan dan ditulis di papan tulis.

5.Anggota dari setiap kelompok yang ditunjuk, menuliskan istilah beserta definisinya pada papan tulis berdasarkan topik yang telah dipelajari dari hasil diskusi kelompok.

6.Siswa saling memberikan tanggapan mengenai materi yang ditulis di papan tulis.

7.Beri siswa satu menit untuk mengingat daftar yang tertera pada papan tulis.

8.Setelah waktu habis, hapus tulisan yang ada pada papan tulis.

9.Siswa diminta oleh guru untuk menjelaskan kembali mengenai materi yang telah ditulis di papan tulis dan didiskusikan.

10.Siswa harus menjelaskan materi atau daftar istilah dengan mengingat sebanyak yang mereka mampu.

11.Guru serta peserta didik berkolaborasi dalam mengevaluasi pembelajaran yang telah dilaksanakan.
Model pembelajaran Papan Memori pada kenyataannya memiliki keunggulan dan kelemahan. Keunggulan dan kelemahan model pembelajaran papan memori dikemukakan Ginnis (2008: 146) sebagai berikut.

Keunggulan model pembelajaran Papan Memori membuat setiap siswa dapat berperan aktif dalam proses pembelajaran, permainan dalam pembelajaran yang menggunakan model Papan Memori menimbulkan keceriaan saat siswa melaksanakan tugas-tugas belajar yang dapat menimbulkan rasa bosan, siswa dapat bekerja sama dan saling bersosialisasi dengan siswa yang lainnya, siswa juga bukan hanya mampu dalam bidang sastra saja tetapi juga dalam berbahasa karena sikap berbahasa siswa dalam proses belajar diperhatikan, mencerdaskan cara berpikir siswa, menumbuhkan kecerdasan emosional dan kemandirian. Adapun kelemahannya yakni siswa dapat saling ketergantungan dan tidak semua siswa dapat berhasil dalam belajar hanya dengan mengandalkan ingatannya.

\section{Hakikat Menyimak}

Aspek yang lebih ditekankan dalam penelitian ini, yakni aspek mendengarkan/menyimak. Siswa diharapkan mampu memahami isi cerpen yang dibacakan dan dapat menyebutkan unsur intrinsik (alur, latar, tokoh dan penokohan) serta dapat mengidentifikasi nilai-nilai yang terdapat dalam sebuah cerita 
pendek. Kegiatan pembelajaran memahami pembacaan cerpen ini termasuk pada aspek keterampilan mendengarkan. Mendengarkan atau menyimak pada hakikatnya adalah termasuk ke dalam keterampilan berbahasa. Tarigan (1986: 19) menyatakan bahwa kegiatan menyimak merupakan serangkaian proses mendengarkan secara penuh konsentrasi ujaran-ujaran dari lisan dengan penuh pemahaman, perhatian, apresiasi, serta interpretasi untuk mendapatkan informasi, menangkap isi, serta memahami makna komunikasi yang disampaikan pembicara melalui komunikasi lisan.

Berdasar dari penjelasan sebelumnya, penulis dapat menarik simpulan bahwa kegiatan menyimak adalah tindakan atau kegiatan mental dalam memaknai, memahami, menimbang, dan merespons isi pesan yang terkandung dalam simbolsimbol bahasa lisan. Menyimak merupakan kategori keterampilan berbahasa yang bersifat reseptif. Dalam kegiatan menyimak, syarafsyaraf pendengaran dan mental kita pada saat menangkap bunyi dan memahami makna sangatlah aktif. Heryadi (2008: 11) mengemukakan kemampuan dasar menyimak meliputi hal-hal berirkut ini.

1.Kompetensi memusatkan perhatian (mampu berkonsentrasi).

2.Kompetensi menangkap suara.

3.Kompetensi memahami unsur linguistik dan nonlinguistik.

4.Kemampuan memverifikasi.

5.Kemampuan merespons.
6.Kemampuan mengingat.

Keberhasilan menyimak dipengaruhi oleh beberapa faktor sebagai berikut.

a.Aspek Pembicara

Pembicara yang menguasai materi yang dibicarakannya, dan memiliki sifat simpatik terhadap penyimak, serta menguasai/memiliki gaya bicara yang menarik dipastikan dapat menarik dan meyakinkan bagi penyimak.

b.Aspek Pembicaraan

Pembicaraan yang meliputi isi dan bentuknya memiliki karakteristik tertentu. Isi atau materi pembicaraan yang baru, menarik, sistematikanya tersusun runtut, dan tingkat kesukarannya sesuai dengan kemampuan penyimak dapat menggugah motivasi penyimak untuk menyimak dengan sungguhsungguh.

c.Aspek Situasi

Segala hal yang menyertai penyimak di luar pembicaraan, dan menyimak. Situasi meliputi tempat, waktu berlangsung dan suasana lingkungan. Tempat yang menyenangkan, waktu berlangsungnya pada jam yang tepat, dan suasana lingkungan yang tenang dapat mendukung keberhasilan menyimak.

d.Aspek Penyimak

Faktor yang terdapat pada diri penyimak yang meliputi faktor fisik dan psikologis. Faktor fisik berhubungan dengan kesehatan fisik penyimak, sedangkan faktor psikologis berhubungan dengan 
kesehatan mental, minat dan kecerdasan penyimak.

Keempat faktor tersebut saling terkait dan saling mendukung untuk mencapai keberhasilan menyimak. Adapun yang paling dominan dari keempat faktor tersebut, yakni faktor penyimak. Sebab walaupun ketiga faktor lainnya sudah demikian baik, jika penyimak tidak memiliki kemampuan dasar menyimak, dan tidak memiliki kondisi fisik dan psikologi yang baik, maka keberhasilan menyimak masih sulit dicapai. Kegiatan menyimak ini berkaitan dengan pembelajaran memahami pembacaan cerpen.

\section{Hakikat Cerpen}

Cerpen adalah cerita yang tidak panjang atau pendek. Akan tetapi, seberapa tingkat panjang atau pendeknya memang tidak diatur. Artinya, tidak ada kesepakatan yang pasti di antara para pengarang. Nurgiyantoro (2002:

mengemukakan bahwa cerita pendek yaitu sebuah cerita yang dapat selesai dibaca dalam sekali duduk, dan perkiraan dapat dibaca antara setengah sampai dua jam.

Cerita pendek adalah karya yang bersifat fiksi. Istilah fiksi memiliki arti, yakni cerita rekaan atau cerita khayalan. Karya fiksi sebagai sebuah karya imajinatif menawarkan masalah kehidupan manusia dan kemanusiaan, hidup dan kehidupan. Fiksi yaitu bersifat imajiner, tetapi biasanya masuk akal dan mengandung kebenaran yang mendramatisasikan hubunganhubungan antarmanusia. Sumardjo (1984: 69) mengatakan "cerpen adalah cerita yang membatasi diri dalam membahas salah satu unsur fisik dalam aspeknya yang terkecil. Kependekan sebuah cerita pendek bukan karena bentuknya yang lebih pendek daripada novel, tetapi aspek masalahnya sangat dibatasi. Dengan pembatas ini maka sebuah masalah tergambarkan jauh lebih jelas dan jauh lebih mengesankan bagi pembaca. Kesan yang ditinggalkan oleh sebuah cerita pendek harus tajam dan dalam, sehingga sekali membacanya kita tidak mudah lupa."

Cerpen mudah diingat tetapi terkadang sulit dipahami apabila bahasa yang digunakannya berbelitbelit atau banyak kata-kata asing yang baru dikenal, karena pengarang ada juga yang suka menggunakan beberapa kata dari bahasa daerah.

Berdasarkan

pendapat sebelumnya, dapat penulis simpulkan bahwa cerita pendek adalah suatu karya sastra cerita fiksi yang singkat dan dapat selesai dibaca dalam satu kali duduk, serta menggambarkan sebuah pengalaman peristiwa yang dialami oleh si pelaku cerita secara jelas.

Cerita pendek sebagai salah satu bentuk karya sastra dibangun oleh dua lapis sebagai berikut.

\section{Lapis Bentuk}
a. Latar/setting.
b. Alur/jalan cerita.
c. Tokoh dan Penokohan.
d. Sudut Pandang/titik kisah.
e. Gaya. 


\section{Lapis Makna}

a. Tema.

b. Amanat.

c. Tegangan (suspensi).

d. Pembayangan.

e. Nada.

f. Suasana.

Penjelasan tersebut dapat disimpulkan bahwa seorang pengarang dalam menyusun karyanya harus memperhatikan unsur-unsur pembangun karya sastra yang meliputi lapis bentuk dan lapis makna karena antar unsur-unsur tersebut saling terhubung dan mendukung.

Kegiatan pembelajaran di atas, penulis laksanakan dengan menerapkan model pembelajaran Papan Memori. Model pembelajaran Papan Memori yaitu model yang merupakan suatu permainan yang cepat dan mudah untuk membantu siswa dalam hal daya ingat dan definisi teknis. Dengan menggunakan model pembelajaran Papan Memori membuat siswa menjadi aktif dan menjadi subjek belajar.

\section{METODE PENELITIAN}

Yang dimaksud metode penelitian yaitu serangkaian cara untuk pelaksanaan penelitian yang sudah dirancang berdasarkan pendekatan yang digunakan. Pelaksanaan penelitian ini dilakukan dengan menggunakan metode penelitian eksperimen, dengan alasan karena ingin mengetahui model pembelajaran yang lebih baik untuk digunakan dalam meningkatkan kemampuan pemahaman bahasa Indonesia siswa dalam materi memahami pembacaan cerpen.

Dalam penelitian ini, penulis memberikan perlakuan kepada sampel. Perlakuan yang dimaksud adalah pembelajaran mendengarkan dan memahami pembacaan cerpen serta mengidentifikasi unsur intrinsik dan nilai yang terkandung dalam cerpen. Untuk menjaga keobjektifan penelitian ini, penulis menggunakan kelas kontrol. Di kelas kontrol, penulis memberikan perlakuan berupa pembelajaran mendengarkan dan menganalisis cerpen tanpa menggunakan model papan memori tetapi menggunakan metode yang biasa dilakukan oleh guru setempat. Dalam hal ini, penulis berupaya mengkomparasikan hasil pembelajaran yang menggunakan model pembelajaran papan memori dengan pembelajaran yang tidak menggunakan model pembelajaran Papan Memori.

Karakter penelitian yang penulis lakukan sesuai dengan yang dikemukakan Heryadi (2008: 48-49) bahwa metode eksperimen adalah metode penelitian yang digunakan untuk menyelidiki hubungan sebab akibat (hubungan pengruh) antara variabel yang diteliti. Untuk mengetahui bahwa variabel $\mathrm{X}$ menjadi sebab atau pengaruh terhadap variable $\mathrm{Y}$ dapat dilakukan dengan men-treatmen-kan variabel $\mathrm{X}$ terhadap kelompok sampel sebagai kelompok eksperimen, kemudian dilakukan pengukuran variabel $\mathrm{Y}$ 
terhadap kelompok sampel tersebut untuk diketahui pengaruh perlakuan $\mathrm{X}$ terhadap $\mathrm{Y}$. Pengumpulan data pada penelitian ini menggunakan teknik tes awal (pre-test) pada sebelum pembelajaran dilakukan dan tes akhir (post-test) setelah pembelajaran selesai dilaksanakan. Instrumen yang digunakan harus memenuhi persyaratan sebagai instrumen yang baik. Menurut Russefendi, E. T. (2005: 147)"....alat evaluasi yang baik atau instrumen yang baik adalah harus memenuhi syarat sebagai alat evaluasi yang baik. Dua dari persyaratan yang penting itu adalah validitas dan reliabilitasnya harus tinggi. Instrumen yang digunakan dalam penelitian ini berupa soal tes pemahaman pembacaan cerpen yang diberikan sebagai pre-test dan posttest.

\section{HASIL DAN PEMBAHASAN}

Aktivitas penelitian yang dilaksanakan di kelas eksperimen dengan menggunakan model pembelajaran kooperatif tipe papan memori dilakukan di kelas XI IPS 1 yang berjumlah 22 orang. Kegiatan awal yang dilaksanakan di kelas eksperimen yakni penulis mengajak siswa mempersiapkan diri untuk mengikuti pembelajaran. Sebagai upaya untuk menumbuhkan motivasi belajar para siswa, penulis memberikan beberapa pertanyaan yang berkaitan dengan masalah unsur sastra yang terdapat dalam cerita pendek "Shalawat Badar" yang diperdengarkan sebagai pretes, khususnya unsur intrinsik (alur, latar, tokoh dan penokohan), nilai-nilai yang terkandung dalam cerpen serta menceritakan kembali cerpen yang diperdengarkan, yakni cerpen yang berjudul "Shalawat Badar". Setelah siswa selesai menjawab pertanyaan yang diajukan sebagai pretes, siswa pada kelas eksperimen melaksanakan kegiatan belajar dengan memakai model pembelajaran Papan Memori. Selanjutnya setelah selesai pembelajaran, siswa diberikan soal kembali yang berkaitan dengan unsur intrinsik (alur, latar, tokoh dan penokohan), nilai-nilai yang terkandung dalam cerpen serta menceritakan kembali cerpen "Tiong Ohang" yang diperdengarkan kembali sebagai kegiatan postes.

Kegiatan penelitian yang dilaksanakan di kelas kontrol tanpa menggunakan model pembelajaran kooperatif tipe papan memori dilaksanakan di kelas XI IPS 2 yang bersiswa 23 orang. Kegiatan awal yang dilakukan di kelas kontrol adalah penulis mengajak siswa mempersiapkan diri untuk mengikuti pembelajaran. Sebagai upaya untuk menumbuhkan motivasi belajar para siswa, penulis memberikan beberapa pertanyaan yang berkaitan dengan masalah unsur sastra yang terdapat dalam cerita pendek "Shalawat Badar" yang diperdengarkan sebagai pretes, khususnya unsur intrinsik (jalan cerita, latar, tokoh dan penokohan), nilai-nilai yang terkandung dalam cerpen serta menceritakan kembali cerpen yang 
diperdengarkan yaitu cerpen yang berjudul "Shalawat Badar". Penelitian di kelas kontrol dilakukan menggunakan instrumen yang sama dengan pretes dan postes, yang berbeda yaitu model pembelajaran yang digunakan. Di kelas kontrol, model pembelajaran yang digunakan bukan Papan Memori.

Berdasar pada data yang melalui proses pengujian analisis statistik didapat beberapa gambaran bahwa penggunaan model pembelajaran kooperatif tipe Papan Memori dengan persiapan yang matang dan pelaksanaan yang optimal dapat menghasilkan yang maksimal pada kemampuan memahami pembacaan cerita pendek siswa. Hal tersebut dapat dilihat berdasarkan rerata gain ternormalisasi yang diperoleh siswa pada kelas eksperimen, yaitu 0,38. Adapun rata-rata gain ternormalisasi yang diperoleh siswa pada kelas kontrol yang tidak menggunakan model papan memori adalah 0,27. Kedua rata-rata tersebut dapat digambarkan pada diagram 1 berikut.

Diagram 1

Gain Ternormalisasi Kelas Eksperimen dan Kelas Kontrol

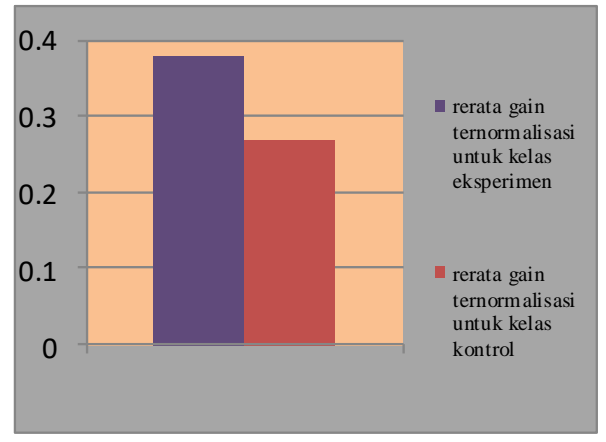

204 | Jurnal Kredo Vol. 2 No. 2 April 2019
Pengolahan dan perolehan data yang didapat dengan analisis statistik, menunjukkan peningkatan kemampuan memahami pembacaan cerpen dengan menggunakan model pembelajaran kooperatif tipe Papan Memori lebih baik daripada dengan menggunakan model pembelajaran diskusi kelas biasa (tanpa menggunakan model Papan Memori). Hal tersebut dikarenakan dalam pelaksanaan pembelajaran kooperatif tipe Papan Memori memiliki langkah yang menjadi kunci dalam memotivasi siswa untuk aktif berusaha memahami materi, yakni memahami pembacaan cerpen. Model pembelajaran Papan Memori membuat siswa mendapat kesempatan untuk saling bertukar saran atau pendapat atau pemikiran yang dimiliki siswa dalam memahami suatu permasalahan sehingga kemampuan eksplorasi dan pemahaman tergali dan bertambah dengan adanya sumbangan pemikiran dari siswa lainnya serta bimbingan dari guru.

\section{SIMPULAN}

Berpijak pada hasil penelitian, pengolahan dan analisis data secara statistika maka simpulan penelitian ini, yakni model pembelajaran Papan Memori lebih berpengaruh dalam meningkatkan kemampuan memahami pembacaan cerpen daripada dengan model diskusi kelompok biasa atau tanpa menggunakan model pembelajaran Papan Memori. Perihal tersebut 
dapat dilihat yakni nilai rata-rata gain ternormalisasi untuk kelas eksperimen yang pembelajarannya dilaksanakan dengan model pembelajaran kooperatif tipe Papan Memori adalah 0,38. Adapun untuk kelas kontrol yang pembelajarannya tanpa menggunakan model pembelajaran Papan Memori adalah 0,27 . Nilai rata-rata kelas pada pembelajarannya mengaplikasikan model pembelajaran kooperatif tipe Papan Memori lebih tinggi daripada kelas yang proses pembelajarannya tanpa menggunakan model pembelajaran Papan Memori. Hal ini menjadi indikasi bahwa siswa pada kelas eksperimen lebih banyak yang mendapatkan skor yang lebih tinggi daripada siswa pada kelas kontrol. Selain itu, nilai median, modus, serta simpangan baku dari kedua kelas menunjukan hal yang sama. Nilai median, modus, dan simpangan baku pada kelas yang kegiatan pembelajarannya mengaplikasikan model pembelajaran kooperatif tipe Papan Memori diperoleh nilai yang lebih unggul daripada kelas yang proses pembelajarannya tanpa penggunaan model pembelajaran Papan Memori.

\section{DAFTAR PUSTAKA}

Ginnis, Paul. 2008. Trik dan Taktik Mengajar. Jakarta: PT Indeks.

Heryadi, Dedi. 2008. Kemahiran Menyimak (Teori dan Pembelajaran). Tasikmalaya: Universitas Siliwangi.

Heryadi, Dedi. 2008. Metode Penelitian Pendidikan Bahasa. Tasikmalaya: Universitas Siliwangi.

Jamaluddin. 2003. Problematik Pembelajaran Bahasa dan Sastra. Yogyakarta: Adicita Karya Nusa

Nurgiyantoro, Burhan. 2002. Teori Pengkajian Fiksi. Yogyakarta: Gadjah Mada University Press.

Ruseffendi, H. E. T. 2005. Dasar-dasar Penelitian Pendidikan \& Bidang NonEksakta Lainnya. Bandung: Tarsito.

Sumardjo, Jakob, Saini K. M. 1988. Apresiasi Kesusastraan. Jakarta: Gramedia.

Tarigan, Henry Guntur. 1986. Menyimak Sebagai Suatu Keterampilan Berbahasa. Bandung: Angkasa. 